\title{
Toxic Extracts in Ponderosa Pine Needles that Produce Abortion in Mice
}

\author{
C. COGSWELL AND L.D. KAMSTRA
}

\begin{abstract}
A reliable method to measure presence and quantity of the toxic factor in needles of ponderosa pine (Pinus ponderosa Laws.) was developed using embryo implantation and gestation in laboratory mice as the basis of the assay. The abortiofacient factor was present in both aqueous and acetone extracts of ponderosa pine needles. Control animals had significantly $(\boldsymbol{P}<0.1)$ greater number of viable embryos at 124, 148, and $172 \mathrm{hr}$ post-coitum than mice fed pine needle extracts. A gestation study verified results from the implantation experiment, as few mice fed pine needle extracts delivered normal litters. Frequently, mice receiving the concentrated aqueous extract had diarrhea and decreased feed intake. Failure of implantation by $124 \mathrm{hr}$ postcoitum in bred mice fed aqueous or acetone extracts of ponderosa pine can be used as an index of the risk involved in grazing ponderosa pine ranges, but cannot be used to predict losses.
\end{abstract}

Ponderosa pine (Pinus ponderosa Laws.) needle abortion, first described by Bruce (1927), has been a frequent problem for ranchers and veterinarians in the western United States and Canada. Abortions resulting from the ingestion of pine needles occurred with greater frequency in the last trimester of gestation in beef cows (MacDonald 1952; Faulkner 1969; Stevenson et al. 1972; James et al. 1977). Research has not established whether cows are less susceptible to toxicity of pine needles or whether fewer needles are consumed in early gestation when there is adequate forage than in the later stages of gestation when less forage is available. However, aborting cows have retained placentas regardless of the gestational stage when needles are eaten. Majak et al. (1977) replaced the drinking water of cows in the last trimester of pregnancy with an aqueous extract of pine needles without initiating abortions. Toner (1971) found that plasma estrogen levels decreased when bred heifers were drenched with a slurry of ground ponderosa pine needles and

\footnotetext{
Authors are former research assistant and professor of Animal Science. South Dakota State University, Brookings 57007.

This study is published with the approval of the Director of the South Dakota Experiment Station as Publication No. 1591 of the Journal Series.

Manuscript received November $11,1978$.
}

water. When feeds were pelleted, the toxic factor apparently was destroyed by heat (Faulkner 1969; Chow et al. 1972). The effect of pine needles upon reproduction in sheep and wildlife, particularly deer, has not been definitely determined (Stevenson et al. 1972).

The extremely high cost of using sufficient numbers of large animals with long gestation periods has made it desirable to use laboratory animals for exploratory research into the cause of ponderosa pine needle abortion. Data from rat and mouse research indicated aqueous and chloroform extracts of ponderosa pine needles contained anticstrogenic properties as evidenced by decreased uterine weights of immature mice (Allen and Kitts 1961; Cook and Kitts 1964; Allison and Kitts 1964). However, Allen and Kitts (1961) also prepared other extracts composed of unidentified noncrystalline material which showed slightly estrogenic activity. Research of Chow et al. (1972) and Anderson and Lozana (1977) indicated the toxic factor caused a disruption of gestation during early fetal development in bred mice. The factor also appeared to be cumulative since bred mice fed pine needle extracts for a longer time produced smaller litters (Chow et al. 1972). Later research failed to substantiate consistent early fetal toxicity using an aqueous pine needle extract (Chow et al. 1972).

\section{Materials and Methods}

At monthly intervals from November through April, fresh ponderosa pine needles were collected from a foothill pine range near Sturgis, South Dakota. Branches were stripped of needles up to the estimated grazing height of cattle. Samples of $100 \mathrm{~g}$ each were macerated in a Waring blender and washed twice with $400 \mathrm{cc}$ of distilled water. The filtrate was freeze-dried and termed the aqueous extract. Solids remaining after the previous extraction were transferred to a blender and extracted with $200 \mathrm{cc}$ portions of acetone. The green filtrate was freeze-dried and designated as the acetone extract. Freeze-dried extracts were incorporated at $1: 1$ and 2:1 ratios of extract with the control feed, Purina Mouse Chow ${ }^{1}$. The amount of the extract

\footnotetext{
'Mention of trade names does not imply an endorsement of Purina Mouse Chow.
} 
added to the control feed was based upon the weight of fresh ponderosa pine needles which were extracted. For example, a 1:1 ration means that the extract from $1 \mathrm{~g}$ of pine needles was added to $1 \mathrm{~g}$ of feed.

\section{Early Embryo Survival Study}

Experimental animals were selected from a colony of the BALB/c strain of mice derived originally from breeding stock obtained from Jackson Laboratory (Bar Harbor, Maine). Twenty-four virgin female mice were randomly mated, and mice with vaginal plugs were placed on experiment to evaluate each of the six collection dates. At one day post-coitum (pc), the mice were allotted by randomization into four groups of six mice per ration as follows: control, aqueous $1: 1$, aqueous $2: 1$, and acetone $1: 1$. Two mice per treatment were sacrificed and uteri examined for viable embryos at 124,148 , and $172 \mathrm{hr}$ pc. Data were analyzed using procedures for least square analysis of variance (Steele and Torrie 1960).

\section{Gestation Study}

To determine how feeding of pine needle extracts through gestation affected pregnancy, 38 virgin females were randomly mated. Two bred mice used as controls were fed ground Purina Mouse Chow. Bred pairs of mice selected by restricted randomization considering initial weight were placed on each of the following treatments: aqueous $1: 1$, aqueous $2: 1$, and acetone $1: 1$ rations prepared from each collection of pine needles. Number of mice giving birth, size of litter, and total number of young dying after birth were recorded. If a mouse failed to deliver at the expected time, the mouse was sacrificed and the reproductive tract examined. Data were analyzed using chi-square procedures (Steele and Torrie 1960).

\section{Results}

\section{Farly Embryo Survival Study}

Early embryo survival was significantly reduced $(P<.01)$ in mice fed extracts from the January 5 and April 26 collections of pine needles (Tables 1 and 2). The numbers of surviving embryos from mice fed these two collections were only 61 and $58 \%$ as great, respectively, as from the mean of mice fed the other collections. The reasons for the toxicity of the extracts from these collections is not known. The duration of feeding had no significant effect and the two-factor and three-factor interactions of collection data, kind of extract and duration of feeding were not significant.

The difference in the number of embryos surviving from mice fed the different extracts was highly significant $(P<.01$, Table 1). The mean of each extract was significantly different from the others $(P<.01$, Table 2$)$. Only $64 \%$ as many embryos survived from the aqueous $1: 1$ ration and only $9 \%$ as many embryos from the aqueous 2:1 ration as from the control ration. The acetone ration was more toxic than the aqueous 1:1 ration but not as toxic as the aqueous $2: 1$ ration. Since the acetone extraction was done on samples from which the aqueous extract had been made, a different toxin may have been present.

Table 1. Analysis of variance for pine needle extracts upon number of embroys surviving in bred mice.

\begin{tabular}{lcc}
\hline Source & $d f$ & Mean square \\
\hline Collection time (C) & 5 & $18.2^{*}$ \\
Extract (E) & 3 & $243.4^{* *}$ \\
Duration of fccding (D) & 2 & 9.5 \\
CXE & 15 & 11.5 \\
CXD & 10 & 11.6 \\
EXD & 6 & 8.2 \\
CXEXD & 30 & 7.0 \\
Residual & 72 & 7.3 \\
\hline
\end{tabular}

Table 2. Ponderosa pine needle collection periods and number of embroys surviving in bred mice. ${ }^{1}$

\begin{tabular}{lcccccc}
\hline & \multicolumn{9}{c}{ Treatment } & & \\
\cline { 2 - 5 } $\begin{array}{l}\text { Collection } \\
\text { date }\end{array}$ & Control & $\begin{array}{c}\text { Aqueous } \\
1: 1\end{array}$ & $\begin{array}{c}\text { Aqueous } \\
2: 1\end{array}$ & $\begin{array}{c}\text { Acetone } \\
1: 1\end{array}$ & $X^{2}$ & $S . E$. \\
\hline Nov. 30 & 15.0 & 12.3 & 2.0 & 3.3 & $8.2^{a}$ & .66 \\
Jan. 5 & 13.0 & 6.0 & 0.0 & 0.0 & $4.8^{b}$ & .53 \\
Jan. 21 & 10.3 & 9.0 & 0.0 & 11.7 & $7.8^{a}$ & .12 \\
Feb. 28 & 15.3 & 12.3 & 0.0 & 3.7 & $7.8^{a}$ & .26 \\
Mar. 23 & 13.3 & 7.7 & 3.7 & 7.0 & $7.9^{a}$ & .32 \\
Apr. 26 & 12.0 & 3.0 & 1.3 & 2.3 & $4.6^{b}$ & .48 \\
$X^{3}$ & $13.2^{a}$ & $8.4^{b}$ & $1.2^{c}$ & $4.7^{d}$ & & \\
S.E. & .40 & .32 & .43 & .40 & & \\
\hline
\end{tabular}

Each value is the mean number of surviving embryos from six bred mice "Means within the same column with different superscripts are significantly different $(P<.01)$.

Means within the same row with different superscripts are significantly different $(P<.05)$.

Hemorrhagic conditions were common in the uterine tracts of the treated mice, especially in those fed the aqueous $2: 1$ ration, in contrast to the control mice, which had no uterine hemorrhages. Mice fed the aqueous 2:1 ration also had blood-filled uterine tracts. Normal embryo development and size of litter were decreased in mice on the pine needle treatments during the period of rapid cell division at implantation. Many tracts were devoid of embryos and even embryos that survived through this stage of development were smaller in size than the controls. However, bred mice on the stronger aqueous treatment appeared to suffer the most severely, since most uterine tracts were shrunken in size, blood-filled and devoid of embryos at the time of sacrifice.

\section{Gestation Study}

This research indicated that the toxic effect was cumulative, similar to the findings of Chow et al. (1972): the longer bred mice were maintained on pine needle rations the less likely viable embryo survived to term. Aqueous $1: 1$ and acetone $1: 1$ rations were readily consumed by mice throughout gestation. Nearly all mice fed the aqueous 2:1 extract consumed less feed than mice on other treatments. These mice were also nervous and frequently had diarrhea.

The proportion of mice giving birth was significantly greater in the group fed the control ration than in the groups fed the pine needle extracts $(100$ vs $17 \%, P<.025$, Tables 3 and 4$)$. However, there was no significant difference in the proportion of mice giving birth due to the three different extracts, the six different collection dates, or to interaction between these effects (Table 3).

The proportion of mice alive 3 days after birth was significantly greater in the group fed the control ration than ir those fed the extracts $(8.50$ vs 0.75 live young per bred mouse.

Table 3. Chi-square analyses of data from the gestation study

\begin{tabular}{|c|c|c|c|c|}
\hline Attribute & Comparison & $X^{2}$ & d.f. & $P$ \\
\hline \multirow{4}{*}{$\begin{array}{c}\text { Number mice giving } \\
\text { birth }\end{array}$} & Control vs extracts & 6.24 & 1 & $<.25$ \\
\hline & Three extracts & 3.00 & 2 & $<.250$ \\
\hline & Collection dates & 2.00 & 5 & $<.900$ \\
\hline & Extracts $\times$ dates & 1.66 & 10 & $<.995$ \\
\hline \multirow{4}{*}{$\begin{array}{l}\text { Number mice alive } \\
3 \text { days after birth }\end{array}$} & Control vs extracts & 98.27 & 1 & $<.010$ \\
\hline & Three extracts & 9.56 & 2 & $<.010$ \\
\hline & Collection dates & 10.11 & 5 & $<.100$ \\
\hline & Extracts $\times$ dates & 24.90 & 10 & $<.010$ \\
\hline
\end{tabular}


Table 4. Comparison of pine needle extracts upon pregnancy in mice.

\begin{tabular}{|c|c|c|c|c|}
\hline Treatment & $\begin{array}{l}\text { No. of } \\
\text { bred mice }\end{array}$ & $\begin{array}{l}\text { No. giving } \\
\text { birth }\end{array}$ & $\begin{array}{l}\text { Total no. } \\
\text { born }\end{array}$ & $\begin{array}{c}\text { No. dead } 3 \\
\text { days after birth }\end{array}$ \\
\hline Control & 2 & 2 & 17 & 0 \\
\hline \multicolumn{5}{|l|}{ Nov. 30} \\
\hline Aqueous 1:1 & 2 & 1 & 6 & 1 \\
\hline Aqueous 2:1 & 2 & 0 & 0 & 0 \\
\hline Acetone 1:1 & 2 & 0 & 0 & 0 \\
\hline \multicolumn{5}{|l|}{ Jan. 5} \\
\hline Aqueous 1:1 & 2 & 1 & 5 & 3 \\
\hline Aqueous 2:1 & 2 & 0 & 0 & 0 \\
\hline Acetone $1: 1$ & 2 & 0 & 0 & 0 \\
\hline \multicolumn{5}{|l|}{ Jan. 21} \\
\hline Aqueous 1:1 & 2 & 0 & 0 & 0 \\
\hline Aqueous 2:1 & 2 & 0 & 0 & 0 \\
\hline Acetone 1:1 & 2 & 1 & 8 & 0 \\
\hline \multicolumn{5}{|l|}{ Feb. 28} \\
\hline Aqueous $1: 1$ & 2 & 1 & 3 & 1 \\
\hline Aqueous 2:I & 2 & $1 *$ & 3 & 0 \\
\hline Acetone $1: 1$ & 2 & 0 & 0 & 0 \\
\hline \multicolumn{5}{|l|}{ Mar. 23} \\
\hline Aqueous l:l & 2 & 1 & 7 & 0 \\
\hline Aqueous 2:I & 2 & 0 & 0 & 0 \\
\hline Acetone 1:1 & 2 & 0 & 0 & 0 \\
\hline \multicolumn{5}{|l|}{ Apr. 26} \\
\hline Aqueous 1:1 & 2 & 0 & 0 & 0 \\
\hline Aqueous 2:1 & 2 & 0 & 0 & 0 \\
\hline Acetone 1:1 & 2 & 0 & 0 & 0 \\
\hline
\end{tabular}

Dicd 3 days after parturition.

$P<.005$, Tables 3 and 4). The aqueous 1:1 extract had the largest number of mice alive 3 days after birth, followed by the acetone $1: 1$ and then by the aqueous $2: 1(1.33,0.67$, and 0.25 live young per bred mouse, respectively, $P<.01$ Table 3 and 4$)$. No young wre born to those mice fed extracts from pine needles collected in April. The number of young born to mice fed the January 6 extracts slightly exceeded expectations, but $60 \%$ of them died during the following 3 days. The mice fed extracts from the remaining collections had more young alive 3 days after birth than expected due to chance. (Table $3, P<.10$ ). The interaction of extract $\times$ collection dates was highly significant (Table $3, P<.01$ ). The significant interaction was due primarily to the reproductive performance of mice fed the January 21 extracts. The aqueous $1: 1$ extract usually was the least toxic and produced $59 \%$ of the live mice across all collection dates. However, the mice fed this extract from the January 21 collection did not give birth to any young. In contrast mice fed the acetone 1:1 extract from the other five collection dates produced no young, but when fed extract from the January 21 collection produced an average of 4 young per mouse and all were alive three days after birth (Table 4).

\section{Discussion}

Toxic substances in aqueous and subsequent acetone extracts of ponderosa pine needles interfered with the maintenance of pregnancy in mice. Previous investigations have determined that one or more toxic substances in ponderosa pine needles interfere with reproduction in mice. Since in the present study, early embryo mortality occurred within $124 \mathrm{hr}$ post-coitus in bred mice fed aqueous and acetone extracts of ponderosa pine needles, this method can be used as a quick and economical biological assay for the toxicity of ponderosa pine needles. If parallel reproductive disorders with cattle are demonstrated, then early embryonic mortality in mice could be used as an assay to predict the risk involved in grazing ponderosa pine ranges.

Toxicity of pine needle extracts varied with time of needle collection (Table 2), indicating that the concentration of the toxin probably varies with changing environmental conditions.

Further research is needed (1) to determine the interaction of the environmental variables affecting toxicity of pine needles to mice, (2) to see if mouse toxicity can be used as an assay for toxicity of pine needles to cattle, and (3) to isolate and identify the toxic principle(s).

\section{Literature Cited}

Allen, M.R., and W.D. Kitts. 1961. The effects of yellow (Pinus ponderosa Laws.) needles on the reproductivity of the laboratory mouse. Can. J. Anim. Sci. $41: 1$

Allison, C.A., and W.A. Kitts. 1964. Further studies on the antiestrogenic activity of yellow pine needles. J. Anim. Sci. 23:1155.

Anderson, C.K., and E.A. Lozano. 1977. Pine needle toxicity in pregnant mice. Cornell Vet. 67:229.

Bruce, E.A. 1927. Astragalaus serotinus and other stock poisoning plants of British Columbia. Dominion of Can. Agr. Bull. 88.

Chow, F.C., K.J. Hanson, D.W. Hamar, and R.H. Udall. 1972. Reproductive failure of mice caused by pine needle ingestion. J. Reprod. Fert. 30: 169 .

Chow, F.C., D.W. Hamar, and R.H. Udall. 1974. Mycotoxic effect on the fetal development: Pine needle abortion in mice. J. Reprod. Fert. 40:203.

Cook, H., and W.D. Kitts. 1964. Anti-estrogenic activity in yellow pine needles (Pinus ponderosa). Acta Endocrin. 45:33.

Faulkner, L.C. 1969. Pine needle abortion. In: L.C. Faulkner (Ed.) Aborting Diseases of Livestock. Charles C. Thomas, Springfield, Illinois.

James, F.L., J.W. Call, and A.H. Stevenson. 1977. Experimentally induced pine needle abortion in range cattle. Cornell Vet. 67:294.

MacDonald, M.A 1952. Pine needle abortion in beef cattle. J. Range Manage. $5: 150$.

Majak, W., D.E. Waldern, and A. McLean. 1977. Pine needle water extracts as potential abortive agents in gestating cow diets. J. Range Manage. 30:318.

Steele, G.D., and J.H. Torrie. 1960. Principles and Procedures of Statistics. McGraw-Hill Book Co., Inc. New York, N.Y.

Stevenson, A.H., L.F. James, and J.W. Call. 1972. Pine needle (Pinus ponderosa) induced abortion in range cattle. Cornell Vet. 65:519.

Toner, F.D. 1971. Implications of nutrient deficiencies and gonadal hormone levels on the etiology of pine needle abortion in rats and cattle. MS Thesis. University of Idaho, Moscow. 